\title{
Effects of land use changes on the dynamics of selected soil properties in northeast Wellega, Ethiopia
}

\author{
Alemayehu Adugna ${ }^{1,2}$ and Assefa Abegaz ${ }^{1}$ \\ ${ }^{1}$ Department of Geography and Environmental Studies, Addis Ababa University, Addis Ababa, Ethiopia \\ ${ }^{2}$ Department of Geography and Environmental Studies, Wolaita Sodo University, Wolaita Sodo, Ethiopia
}

Correspondence to: Alemayehu Adugna (alemadug@gmail.com)

Received: 17 September 2015 - Published in SOIL Discuss.: 14 October 2015

Accepted: 5 February 2016 - Published: 12 February 2016

\begin{abstract}
Land use change can have negative or positive effects on soil quality. Our objective was to assess the effects of land uses changes on the dynamics of selected soil physical and chemical properties. Soil samples were collected from three adjacent soil plots under different land uses, namely forestland, grazing land, and cultivated land at $0-15 \mathrm{~cm}$ depth. Changes in soil properties on cultivated and grazing land were computed and compared to forestland, and ANOVA (analysis of variance) was used to test the significance of the changes. Sand and silt proportions, soil organic content, total nitrogen content, acidity, cation exchange capacity, and exchangeable $\mathrm{Ca}^{2+}$ content were higher in forestlands. Exchangeable $\mathrm{Mg}^{2+}$ was highest in grazing land, while clay, available phosphorous, and exchangeable $\mathrm{K}^{+}$were highest in cultivated land. The percentage changes in sand, clay, soil organic matter, cation exchange capacity, and exchangeable $\mathrm{Ca}^{2+}$ and $\mathrm{Mg}^{2+}$ were higher in cultivated land than in grazing land and forestland. In terms of the relation between soil properties, soil organic matter, total nitrogen, cation exchange capacity, and exchangeable $\mathrm{Ca}^{2+}$ were strongly positively correlated with most of soil properties, while available phosphorous and silt have no significant relationship with any of the other considered soil properties. Clay has a negative correlation with all soil properties. Generally, cultivated land has the least concentration of soil physical and chemical properties except clay and available phosphorous, which suggests an increasing degradation rate in soils of cultivated land. So as to increase soil organic matter and other nutrients in the soil of cultivated land, the integrated implementation of land management through compost, cover crops, manures, minimum tillage, crop rotation, and liming to decrease soil acidity are suggested.
\end{abstract}

\section{Introduction}

Land use changes have remarkable effects on the dynamics of soil properties (Biro et al., 2013). Land use changes from forest cover to cultivated land may reduce the input or organic residues that lead to a decline in soil fertility (MuñozRojas et al., 2015), increased rates of erosion (Biro et al., 2013), the loss of soil organic matter and nutrients (Saha and Kukal, 2015), and an accelerated rate of soil degradation (Barua and Haque, 2013). Vegetation cover is, therefore, a key indicator of soil degradation as plants play a role in controlling soil erosion (Kröpfl et al., 2013; Keesstra et al., 2009; Cerdà, 1998). Biro et al. (2013) observed that the expansion of cultivated areas can substantially affect soil nu- trient content by reducing the composition of plant species, net primary productivity, above- and belowground allocation in plants, and nutrient cycling. Soil organic matter is less in extremely degraded areas where overgrazing is manifest. Saha and Kukal (2015) found a higher bulk density and lower macroporosity and water retention in cultivated soils than in soils of grassland and forests. This indicated a degradation of soil properties due to the conversion of natural ecosystems to agricultural systems.

In Ethiopia, rapid population growth and environmental factors lead to the conversion of natural forestland and grassland into cultivated farmland (Tesfahunegn, 2016). Such land use changes have contributed to soil degradation and soil loss by deteriorating the soil physical and chemical proper- 
ties (Karltun et al., 2013). Soil compaction, the loss of soil structure, soil organic matter (SOM) degradation, undulating terrain, highly erosive rainfall, and inappropriate farming practices make soil highly vulnerable to erosion. Soil erosion is highest in cropland $\left(42 \mathrm{Mtha}^{-1}\right.$ average annual rate) compared with $5 \mathrm{Mt} \mathrm{ha}^{-1}$ from grassland. Soil degradation causes the loss of fertile topsoil and reduces the productive capacity of the land. The country lost an estimated USD 1 billion per year from both on-site and off-site changes (Bewket and Teferi, 2009). This has been confirmed by empirical studies carried out in different parts of Ethiopia (for example, Angassa, 2014; De Mûlenaere et al., 2014; Tesfaye et al., 2014; Tesfahunegn, 2016; Asmamaw and Mohamed, 2013; Fantaw and Abdu, 2011; Eyayu et al., 2009). Soil degradation in the area makes it necessary to apply restoration strategies (Mekonnen et al., 2015; Bizoza, 2014; Zhang et al., 2009). Soil protection is fundamental so as to maintain soil services and avoid land degradation (Berendse et al., 2015; Keesstra et al., 2012).

In a study conducted in the Rift Valley area of Ethiopia, Fantaw and Abdu (2011) observed an increase in bulk density and decrease in SOM, total nitrogen (TN), exchangeable cations, and cation exchange capacity (CEC) contents following the conversion of native woodlands into farmland and grazing land. In the Gerado catchment, northeastern Ethiopia, Asmamaw and Mohammed (2013) observed changes in the amount of clay, SOM, and total $\mathrm{N}$ following changes in land use and land cover. Eyayu et al. (2009) reported a declining $\mathrm{pH}$ value and SOM conted in leached and degraded cultivated land when compared to forestland in the Tara Gedam catchment and the adjacent agro-ecosystems of northwestern Ethiopia. Emiru and Gebrekidan (2013) indicated that deforestation has resulted in deterioration of SOM in the soil. Similarly, Tesfahunegn (2016) showed that soil quality indicators varied across the land use and soil management systems, among which natural forestland and protected afforestation areas are the most important systems in maintaining soil quality, whereas cultivated and marginal lands seriously deteriorated the physical soil system. The same author showed that soil organic carbon (SOC), $\mathrm{pH}$, total $\mathrm{N}$, available phosphorous (AP), and clay are significantly higher in natural forest and protected afforestation areas. On the other hand, Yeshanew et al. (2005) found that SOC and total $\mathrm{N}$ at $0-20 \mathrm{~cm}$ depth remained the same after natural forest conversion into eucalyptus plantations in Munesa, Ethiopia. Fantaw et al. (2007) in their study in the Bale Mountains of Ethiopia found no variation in soil organic carbon content after natural forest was converted into grazing land. These conflicting findings suggest that the conversion of forestland into cultivated or grazing land leads to changes in soil physical and chemical properties and that the degradation of the land is not applicable at all times and in all places applicable. This further suggests the need for empirical inquiry into the effects of land use changes on the dynamics of selected soil properties and subsequent degradation of farm house-

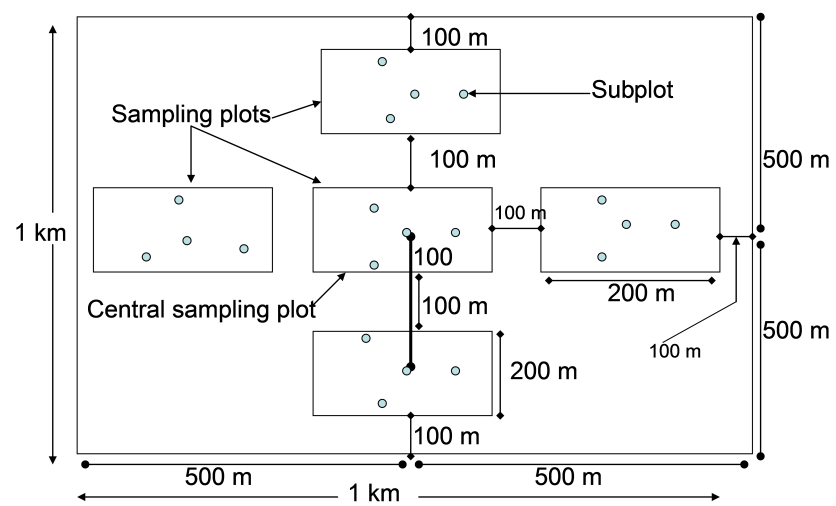

Figure 1. Adapted sampling design of soil samples in northeast Wellega, Ethiopia (after Vågen and Winowiecki, 2013, Vågen et al., 2013, and Abegaz et al., 2016).

hold land. Little work which has implications for land degradation and land management strategies in eastern Africa has been done on the effects of land use on soil properties. Natural forest, comprising tree species such as Podocarptus falcatus (Zigba), Olea europaea (Woyera), and Rosa abyssinica (Kega), was selected as the control field against which different soil properties of cultivated and grazing lands were compared to assess the level of land degradation in northeast Wellega, Ethiopia. The interpretation of our results is limited to the current status of some soil parameters such as soil texture, soil $\mathrm{pH}, \mathrm{TN}, \mathrm{CEC}$, exchangeable cations $\left(\mathrm{Ca}^{2+}, \mathrm{Mg}^{2+}\right.$, $\mathrm{K}^{+}$and $\mathrm{Na}^{+}$), AP, and SOC, due to the fact that there were no documented data on the former land uses.

\section{Materials and methods}

\subsection{Study area}

The study area is located in northeast Wellega (Horo-Guduru Wellega Zone, Oromia Region, Ethiopia; approximate coordinates $\left.9^{\circ} 45^{\prime}-10^{\circ} 00^{\prime} \mathrm{N}, 37^{\circ} 00^{\prime}-37^{\circ} 15^{\prime} \mathrm{E}\right)$. The area belongs to the Trap Series of tertiary volcanic eruptions (ORLEPB, 2013). Its topography is typical of volcanic landscapes, which were later deeply incised by streams, resulting in the current diversity of landforms. The soils have developed from volcanic ashes and reworked materials resulting from tertiary volcanic eruptions and sedimentation processes (ORLEPB, 2013). Nitosols are the dominant soil type, mainly on undulating to steep slopes. Relatively flat areas and especially those closer to river valleys are largely covered by well-developed Vertisols. Dominant soils on steep slopes are Leptosols, Regosols, and Cambisols. The study area has an elevation of between 1800 and $2657 \mathrm{~m}$. The mean annual temperature of the area is $25^{\circ} \mathrm{C}$. Annual rainfall, which is heavy during the summer months (June-August), ranges between 1750 and $2000 \mathrm{~mm}$ (EMA, 2013). For 2013, the population of the study area was projected to be 58339 , 
Table 1. A brief description of the three land use types in northeastern Wellega, Ethiopia.

\begin{tabular}{|c|c|}
\hline Land use & Description \\
\hline Forestland & $\begin{array}{l}\text { Areas covered with tall and dense trees forming a closed or nearly } \\
\text { closed canopy ( } 70-100 \%) \text { and without apparent or reported human } \\
\text { impacts. This unit also includes undercanopy trees mixed with low bushes } \\
\text { and open areas. Dominant tree species in this group include } \\
\text { Celtis africana, Calpurina subdecandra, and Croton mycrostachyus. In } \\
\text { addition, leaf fall, macrofauna (worms, large insects, etc.), } \\
\text { soil microflora (bacteria, fungi, algae, etc.), and microbial activities are } \\
\text { common in this land use. No sign of rill or sheet erosion. }\end{array}$ \\
\hline Grazing land & $\begin{array}{l}\text { Formerly this land use took place under forest cover. Forty years ago, } \\
\text { land use evolved with permanent grass cover, with continuous grazing } \\
\text { systems (information from local elders). Cattle dung is regularly } \\
\text { collected as a source of household energy from this land use. Short grass } \\
\text { species dominate this land unit. In some places rill erosion is observed. }\end{array}$ \\
\hline Cultivated land & $\begin{array}{l}\text { Formerly this land use took place under forest cover. For the last } 40 \text { years, } \\
\text { continuous plowing, clearing and the removal of } \\
\text { aboveground biomass (yield and crop residue), and the leveling of } \\
\text { farming fields (information from local elders) has led to changes. Weathered fragmented rock } \\
\text { materials are common in the plowing soil layer. Structural soil conservation } \\
\text { (rock and earth terracing) practices are common. For the last } 30 \text { years Urea, } \\
\text { and DAP (up to } 100 \mathrm{~kg} \mathrm{ha}^{-1} \text { each) and cattle manure have been applied. } \\
\text { This land includes areas used for rain-fed agriculture. Major crops grown } \\
\text { include cereals (maize, teff, and barley), legumes (beans, peas), and oil crops } \\
\text { (neug). }\end{array}$ \\
\hline
\end{tabular}

of which only $10 \%$ was urban population (CSA, 2008). CSA (2008) reported that the population of the district increased by $39 \%$ from 1980 to 2013. Except for a small percentage of the population living in urban areas, the inhabitants are farmers engaged in mixed crop-livestock farming.

\subsection{Current land use types}

We identified and classified the present land use types through surveys in 2012 and 2013. The information was obtained from elderly members of the community (aged 60 and above), whom we assumed to be knowledgable about the land use types in the local community. Accordingly, three major land use categories, namely forestland, grazing land, and cultivated land, were identified for the purpose of this study (Table 1). Based on the information obtained from the elders, these sites had the same land cover before 1970. Since then, some portions have been converted into cultivated and grazing lands, while some portions remained as forestland.

\subsection{Soil sampling}

The cluster sampling design by Thompson (1991), which was later applied by Vågen et al. (2013), Vågen and Winowiecki (2013), and Abegaz et al. (2016) was modified and used for this study. The study by Vågen et al. (2013) was on the mapping of land degradation prevalence and soil functional properties in Ethiopia; the study of Vågen and Winowiecki (2013) was on mapping of soil organic carbon stocks for spatially explicit assessments of climate change mitigation potential along the Ethiopian and Kenyan highlands; and Abegaz et al. (2016) was on spatial and temporal dynamics of soil organic carbon in landscapes of the upper Blue Nile Basin of the Ethiopian Highlands. In each of these studies, three different areas each $10 \mathrm{~km} \times 10 \mathrm{~km}$ and with 16 clusters or tiles have been used. Since our study is on a small catchment so as to assess the impact of land use differences on selected soil properties, we modified and applied this sampling design to suit our study area.

Accordingly, three adjacent sites under different land use types (forestland, cultivated land, and grazing land) were selected for this study, with similar slope, elevation, and aspect in each land use. We established a $1 \mathrm{~km} \times 1 \mathrm{~km}$ cluster (sampling area) and five cluster centroids (sampling plots) were stratified into $200 \mathrm{~m} \times 200 \mathrm{~m}$ tiles and their locations within the sampling area were chosen systematically (Fig. 1). The first tile (sampling plot) was first established by fixing its central point at the center of a $1 \mathrm{~km} \times 1 \mathrm{~km}$ area. Then, the area of this sampling plot was established using a $100 \mathrm{~m}$ radius from the cluster center (sampling area) point. The centers of the other four sampling plots were established at a $300 \mathrm{~m}$ distance from the center of this sampling plot (the central plot) to the north, east, south, and west. The area of each of these sampling plots was established using a $100 \mathrm{~m}$ radius 
Table 2. Mean variation and standard deviation (SD) of soil fraction, organic matter, total nitrogen, $\mathrm{C}: \mathrm{N}$ ratio, and available phosphorous at $0-15 \mathrm{~cm}$ depth in different land use types in northeastern Wellega, Ethiopia.

\begin{tabular}{|c|c|c|c|c|c|c|c|c|c|c|c|c|c|c|}
\hline \multirow[t]{3}{*}{ Land use type } & \multicolumn{6}{|c|}{ Soil fraction $(\%)$} & \multirow{2}{*}{\multicolumn{2}{|c|}{$\begin{array}{c}\text { Organic } \\
\text { matter }(\%)\end{array}$}} & \multirow{2}{*}{\multicolumn{2}{|c|}{$\begin{array}{c}\text { Total } \\
\text { nitrogen }(\%)\end{array}$}} & \multirow{2}{*}{\multicolumn{2}{|c|}{$\mathrm{C}: \mathrm{N}$ ratio }} & \multirow{2}{*}{\multicolumn{2}{|c|}{$\begin{array}{c}\text { Available } \\
\text { phosphorus (PPM) }\end{array}$}} \\
\hline & \multicolumn{2}{|c|}{ Sand } & \multicolumn{2}{|c|}{ Silt } & \multicolumn{2}{|c|}{ Clay } & & & & & & & & \\
\hline & Mean & SD & Mean & SD & Mean & SD & Mean & SD & Mean & $\mathrm{SD}$ & Mean & SD & Mean & SD \\
\hline Forestland & $51.6^{\mathrm{a}}$ & 3.6 & $32.8^{\mathrm{c}}$ & 1.1 & $15.6^{\mathrm{a}}$ & 2.6 & $9.0^{\mathrm{a}, \mathrm{c}}$ & 1.3 & $0.4^{\mathrm{a}, \mathrm{c}}$ & 0.1 & $12.1^{\mathrm{c}}$ & 0.4 & $3.6^{\mathrm{b}, \mathrm{c}}$ & 1.0 \\
\hline Grazing land & $38.4^{\mathrm{a}}$ & 1.7 & $26.8^{\mathrm{c}}$ & 10.8 & $34.8^{\mathrm{c}}$ & 10.6 & $7.3^{\mathrm{a}, \mathrm{b}, \mathrm{c}}$ & 1.5 & $0.4^{\mathrm{a}, \mathrm{b}, \mathrm{c}}$ & 0.1 & $11.9^{\mathrm{c}}$ & 3.8 & $2.1^{\mathrm{b}}$ & 0.4 \\
\hline Cultivated land & $29.6^{\mathrm{a}}$ & 5.4 & $28.4^{\mathrm{c}}$ & 4.56 & $42.0^{\mathrm{a}, \mathrm{c}}$ & 6.6 & $4.6^{\mathrm{a}, \mathrm{b}}$ & 0.7 & $0.3^{\mathrm{a}, \mathrm{b}}$ & 0.1 & $10.8^{\mathrm{c}}$ & 1.9 & $3.7^{\mathrm{b}, \mathrm{c}}$ & 1.5 \\
\hline
\end{tabular}

Note: ${ }^{\mathrm{a}, \mathrm{b}}$ the mean differences of soil properties in each column are significant at $P<0.01$ and 0.05 , respectively; ${ }^{\mathrm{c}}$ the mean difference is not significant.

from their center point. Thus, a $100 \mathrm{~m}$ buffered area exists between the boarder of the sampling area and the neighboring sampling plots. Within each tile four subplots were randomly established, each with an area of $100 \mathrm{~m}^{2}$ : one in the center and three on radial arms with $120^{\circ}$ angles between them (Vågen and Winowiecki, 2013; Vågen et al., 2013; Abegaz et al., 2016). This form of sampling allows the assessment of variability in soil properties on different spatial scales (Vågen et al., 2013) (in our case among land uses at site level). For each tile, soil samples $(0-15 \mathrm{~cm}$ depth, the average plough layer in the area) were collected from the center of each subplot and composite samples were prepared by hand mixing. In total, we prepared 15 composite soils.

\subsection{Soil analysis}

Composite soil samples were air-dried, ground, and passed through a $2 \mathrm{~mm}$ sieve prior to laboratory analysis. Soil analysis included soil texture (determined by Bouyoucos Hydrometer Method; Black et al., 1965), soil pH (determined in a $1: 2.5$ soil : water ratio), total $\mathrm{N}$ content, cation exchange capacity (CEC), exchangeable cations $\left(\mathrm{Ca}^{2+}, \mathrm{Mg}^{2+}, \mathrm{K}^{+}\right.$, and $\mathrm{Na}^{+}$) by atomic absorption spectrophotometery (AP; Olsen et al., 1954), and organic carbon (OC) content (Walkley and Black, 1934). Soil organic matter (SOM) content (\%) was determined by multiplying the OC percentage by 2 .

\subsection{Statistical analysis}

One-way ANOVA (analysis of variance) was used to analyze the differences in soil texture, $\mathrm{pH}$, available $\mathrm{P}, \mathrm{SOM}, \mathrm{N}$ (Kjeldahl), CEC, and exchangeable cations of the three land use types from 15 composite soil samples (5 from each land use type) at the 0.05 level.

Percentage changes in the soil properties of cultivated land or grazing land compared to forestland $\left(\mathrm{Ch}_{\mathrm{Cl}}, \mathrm{Ch}_{\mathrm{Gl}}\right)$ were computed by

$\mathrm{Ch}_{\mathrm{Cl}, \mathrm{Gr}}=\frac{\mathrm{Lu}_{\mathrm{CI}, \mathrm{or} \mathrm{Gl}}-\mathrm{Lu}_{\mathrm{FI}}}{\mathrm{Lu}_{\mathrm{FI}}} \times 100$,

where $\mathrm{Ch}_{\mathrm{Cl}}, \mathrm{Ch}_{\mathrm{Gl}}$ is the percentage changes in soil property of cultivated or grazing lands compared to forestland and $\mathrm{Lu}_{\mathrm{CI}}, \mathrm{Lu}_{\mathrm{GI}}$, and $\mathrm{Lu}_{\mathrm{FI}}$ are the mean values of the soil property under consideration of cultivated, grazing, and forestland, respectively. Bivariate correlation analysis was conducted to assess the relationships between the studied soil properties.

\section{Results and discussion}

\subsection{Particle size distribution}

The sand content of soils of forestland is the highest and the lowest on soils of cultivated land (Table 2). These differences are statistically significant $(P<0.05$; Table 4$)$. The percentage change in sand particle size distribution is higher in cultivated land than in grazing land and forestland (Table 4). The clay content of soils is the highest in cultivated land and the lowest in soils of forestland (Table 2). The clay fraction on cultivated land and grazing land increased compared to forestland, but the change is greater in cultivated land than grazing land (Table 4). The lower content of sand and higher content of clay fractions in the cultivated land may be attributed to the process of plowing, clearing, and the leveling of farming fields. Because the clay particles are very small in size, silt, and sand fractions could be removed by runoff from the cultivated land. These are deposited in the topsoil of forestland and grazing land (Biro et al., 2013). Differences in the clay content of soil influence the levels of microbial biomass. Clay soils are assumed to hold much more water and plant nutrients than forestland and grazing lands (Karltun et al., 2013). Soils with a high clay content have sufficient particle-to-particle contact points to form strong bonds when the soil dries (Eyayu et al., 2009). Cultivated land with the highest clay fraction has the most compact soils.

\subsection{Soil organic matter, total nitrogen, and available phosphorous}

The content of SOM was the highest in forestlands and the lowest in cultivated land (Table 2), and the differences are statistically significant (Table 4). SOM decreases as forestland land changes into cultivated and grazing land (Table 4). The percentage change is higher in cultivated land than in grazing land (Table 4). The more rapid decrease in SOM contents in cultivated land may be attributed to accelerated rates of erosion and decomposition because these processes were 
Table 3. Mean variation and standard deviation (SD) of soil acidity $(\mathrm{pH})$, cation exchange capacity $(\mathrm{CEC})$, and exchangeable bases $\left(\mathrm{K}^{+}\right.$, $\mathrm{Ca}^{2+}$, and $\mathrm{Mg}^{2+}$ ) at $0-15 \mathrm{~cm}$ depth in different land use types in northeastern Wellega, Ethiopia.

\begin{tabular}{|c|c|c|c|c|c|c|c|c|c|c|}
\hline \multirow[t]{3}{*}{ Land use type } & \multicolumn{2}{|c|}{$\mathrm{pH}\left(1: 2.5 \mathrm{H}_{2} \mathrm{O}\right)$} & \multicolumn{2}{|c|}{$\mathrm{CEC} \mathrm{Cmol}(+) \mathrm{kg}^{-1}$} & \multicolumn{6}{|c|}{ Exchangeable bases $\mathrm{Cmol}(+) \mathrm{kg}^{-1}$} \\
\hline & \multirow[b]{2}{*}{ Mean } & \multirow[b]{2}{*}{ SD } & \multirow[b]{2}{*}{ Mean } & \multirow[b]{2}{*}{ SD } & \multicolumn{2}{|c|}{$\mathrm{K}^{+}$} & \multicolumn{2}{|c|}{$\mathrm{Ca}^{2+}$} & \multicolumn{2}{|c|}{$\mathrm{Mg}^{2+}$} \\
\hline & & & & & Mean & SD & Mean & SD & Mean & SD \\
\hline Forestland & $6.1^{\mathrm{a}, \mathrm{b}}$ & 0.36 & $32.85^{\mathrm{a}}$ & 4.04 & $0.13^{\mathrm{c}}$ & 0.04 & $12.81^{\mathrm{a}}$ & 4.01 & $3.96^{\mathrm{a}, \mathrm{c}}$ & 1.21 \\
\hline Grazing land & $5.7^{\mathrm{c}, \mathrm{b}}$ & 0.22 & $25.65^{\mathrm{a}, \mathrm{b}}$ & 3.32 & $0.12^{\mathrm{c}}$ & 0.07 & $5.98^{\mathrm{a}, \mathrm{c}}$ & 1.34 & $4.80^{\mathrm{a}, \mathrm{c}}$ & 1.10 \\
\hline Cultivated land & $5.4^{\mathrm{a}, \mathrm{c}}$ & 0.13 & $20.19^{\mathrm{a}, \mathrm{b}}$ & 3.66 & $0.14^{\mathrm{c}}$ & 0.08 & $4.08^{\mathrm{c}}$ & 1.79 & $1.71^{\mathrm{a}}$ & 0.27 \\
\hline
\end{tabular}

Note: ${ }^{\mathrm{a}, \mathrm{b}}$ the mean differences of soil properties in each column are significant at $P<0.01$ and 0.05 , respectively; ${ }^{\mathrm{c}}$ the mean difference is not significant.

more active in cultivated lands than forestland and grazing lands (Abegaz et al., 2016). On the other hand, the reduction is less in grazing land because grass roots are fibrous near the soil surface and easily decompose, increasing organic matter. Land management such as poorly designed terracing and cutoff drainage, which was implemented on cultivated land, facilitated the drainage of water and soil from this land and deposited water and soil on forestland. The farming system in the area, which is heavily dependent on traditional practices, also facilitates the removal of topsoil on the cultivated land. This suggests that SOM shows a strong response to land use, land use change, and land degradation (Vågen and Winowiecki, 2013). Thus, the high SOM in forestland is potentially the highest reservoir for the plant essential nutrients nitrogen, phosphorus, and sulfur (Zeng et al., 2009). SOM also increases soil water-holding capacity and CEC and enhances soil aggregation and the structure of soils of forestland.

As expected, the mean value of total $\mathrm{N}$ was highest in soils of forestland and lowest in cultivated land (Table 2). The change in total $\mathrm{N}$ is higher in cultivated land than in grazing land and forestland (Table 4). The $\mathrm{C}: \mathrm{N}$ ratio is the highest in soils of forestland, while it is the lowest in grazing land (Table 2). Due to the close relationship between SOM and total $\mathrm{N}$, the soil $\mathrm{C}: \mathrm{N}$ ratio indicates the status of soil fertility. The $\mathrm{C}: \mathrm{N}$ ratio is often influenced by climate, soil condition, vegetation type, and agricultural management practices (Oedraogo et al., 2006; Zhang et al., 2009). The content of available $\mathrm{P}$ was the highest in cultivated land and the lowest in grazing land (Table 2). The mean differences between soil-available $\mathrm{P}$ of forestland and grazing lands, on the one hand, and cultivated and grazing lands, on the other hand, are statistically significant $(P<0.05$, Table 4$)$, while the mean difference between forestland and cultivated lands is not statistically significant. Compared to the available $\mathrm{P}$ contents of forestland, the available $\mathrm{P}$ of cultivated and grazing lands is increased (Table 4).

Secondary minerals, organic, and inorganic fertilizer are important pools of soil phosphorous (P) (Assefa and van Keulen, 2009). Thus, the fact that soils in the forestland have higher available $\mathrm{P}$ than in the grazing land may have to two reasons. Firstly, even though a pool of available P could be removed by trees in forestland, there is a probability of $\mathrm{P}$ return through litter fall to the soil surface (Asmamaw and Mohammed, 2013). Secondly, microbes, which are abundant in the litter layers of the forest, may quickly add a high proportion of $\mathrm{P}$ under forest cover.

On the other hand, a higher AP in cultivated land than in grazing land may have three reasons. Firstly, cattle dung applied to cultivated fields may increase the level of $\mathrm{P}$ concentration in this land use; on the other hand, while cattle dung is collected, and thus removed, from grazing land (Table 1). Secondly, the frequent application of inorganic $\mathrm{P}$ fertilizer to the cultivated fields (Table 1) may provide a considerable amount of inorganic $\mathrm{P}$ to the soil of cultivated fields. Thirdly, a higher $P$ release as a result of greater weathering processes on cultivated land than on grazing land may provide a higher amount of available $\mathrm{P}$ to the soil of cultivated land. This is because of repeated plowing to prepare the plot for cereal crop production. The finding in this study is in agreement with the observation made by Fantaw and Abdu (2011), also in Ethiopia.

\section{3 $\mathrm{pH}$, cation exchange capacity, and exchangeable basic cations}

The soils in the study land uses have a mean $\mathrm{pH}$ between 5.4 and 6.1 (Table 3). Mean $\mathrm{pH}$ from forest soils was statistically different from the cultivated and grazing land $(P<0.05$; Table 5). Compared to the $\mathrm{pH}$ of soils of forestland, the $\mathrm{pH}$ of soils of cultivated and grazing lands was lower (Table 4). Thus, soils in the cultivated land were more acidic than those of the forestland and grazing lands. This is expected as $13.2 \%$ of Ethiopian soils are strongly to moderately acidic ( $\mathrm{pH}<5.5)$ (Ermias et al., 2013). This is because of intensive farming over a number of years with nitrogen fertilizers on cultivated land. Soil acidity is also a consequence of the leaching of basic cations in soils due to high rainfall, which results in rapid erosion. Cultivated land is characterized by the acidifying effects of acid-forming nitrogen fertilizer, poor nutrient cycling, and the mining of basic cations through harvested crops, soil erosion, and acid rain. 
Table 4. Percentage changes in selected soil properties in cultivated and grazing land uses compared to forestland in northeastern Wellega, Ethiopia.

\begin{tabular}{lccccccccccc}
\hline LU type & Sand & Silt & Clay & $\mathrm{pH}$ & $\mathrm{AP}$ & $\mathrm{OM}$ & $\mathrm{TN}$ & $\mathrm{CEC}$ & $\mathrm{EK}^{+}$ & $\mathrm{ECa}^{2+}$ & $\mathrm{EMg}^{2+}$ \\
\hline Cropland & -43 & -13 & +169 & -11.5 & +2.8 & -49 & -43 & -38.5 & +7.7 & -68 & -56.8 \\
Grassland & -26 & -18 & +123 & -6.6 & -42 & -19 & -16 & -22 & -7.7 & -54 & +21.2 \\
\hline
\end{tabular}

Notes: $\mathrm{LU}$ - land use; $\mathrm{EK}^{+}{ }_{-}$exchangeable $\mathrm{K}^{+} ; \mathrm{Eca}^{2+}{ }_{-}$exchangeable $\mathrm{Ca}^{2+} ; \mathrm{EMg}^{2+}{ }_{-}$exchangeable $\mathrm{Mg}^{2+} ;-$ indicates loss and + indicates gains.

Table 5. The correlation matrix for selected soil properties at $0-15 \mathrm{~cm}$ depth in northeastern Wellega, Ethiopia.

\begin{tabular}{lllllllc}
\hline & $\mathrm{OM}$ & $\mathrm{TN}$ & $\mathrm{CEC}$ & $\mathrm{Ca}^{2+}$ & $\mathrm{Mg}^{2+}$ & $\mathrm{pH}$ & Silt \\
\hline $\mathrm{TN}$ & $0.80^{* *}$ & & & & & & \\
$\mathrm{CEC}$ & $0.80^{* *}$ & $0.81^{* *}$ & & & & & \\
$\mathrm{Ca}$ & $0.82^{* *}$ & $0.76^{* *}$ & $0.89^{* *}$ & & & & \\
$\mathrm{Mg}$ & $0.71^{* *}$ & $0.67^{* *}$ & $0.65^{* *}$ & $0.52^{*}$ & & & \\
$\mathrm{pH}$ & $0.83^{* *}$ & $0.76^{* *}$ & $0.89^{* *}$ & $0.88^{* *}$ & $0.71^{* *}$ & & \\
$\mathrm{Clay}$ & $-0.74^{* *}$ & $-0.54^{*}$ & $-0.77^{* *}$ & $-0.74^{* *}$ & -0.32 & $-0.71^{* *}$ & $-0.69^{* *}$ \\
\hline
\end{tabular}

**, ${ }^{*}$ Correlations are significant at the 0.01 level and at the 0.05 level, respectively (two-tailed).

Soil acidity affects the process of other nutrient transformations, solubility, or plant availability of many plant essential nutrients (Barua and Haque, 2013). In acid soils $(\mathrm{pH}<6$ ), nitrification will be slow and plants with the ability to take up $\mathrm{NH}^{+4}$ may have an advantage (Parras-Alcántra et al., 2013). Thus, in the study area, nitrification will be slow in cultivated land due to the acidity of soil. Acid soils affect the quantity, activity, and types of microorganisms in soils, which in turn influence the decomposition of organic materials (De Mûlenaere et al., 2014; Emiru and Gebrekidan, 2013). Acid soil prone areas are characterized by aluminum and manganese toxic to crop growth, constrained productivity through stunted growth, a poor response to applied fertilizer, and vulnerability to drought. In Ethiopia, soil management strategies such as the application of mineral fertilizers, lime, compost, and manure are used to ameliorate soil acidity. Soil liming can increase soil $\mathrm{pH}$, supply essential plant nutrients (exchangeable $\mathrm{Ca}^{2+}$ and $\mathrm{Mg}^{2+}$ ), make other essential nutrients more available, and prevent $\mathrm{Mn}$ and $\mathrm{Al}$ from being toxic to plant growth (Yao et al., 2010).

The mean CEC was highest in forestland and lowest in cultivated land (Table 3 ), and the differences between land uses are statistically significant $(P<0.05$; Table 5$)$. Compared to the CEC of the soils of forestland, the CEC of the soils of cultivated and grazing lands were decreased (Table 4). Mean exchangeable $\mathrm{Ca}^{2+}$ content was highest in forestland and lowest in cultivated land (Table 3 ). The mean differences between forestland and cultivated lands and forestland and grazing lands are statistically significant $(P<0.05$, Table 5$)$. The mean exchangeable $\mathrm{Mg}^{2+}$ was highest in grazing land and lowest in cultivated land (Table 3). Exchangeable $\mathrm{Ca}^{2+}$ was highest in forestland and lowest in cultivated land (Ta- ble 3). Compared to the soils of forestland, the overall pattern of CEC and exchangeable $\mathrm{Ca}^{2+}$, and $\mathrm{Mg}^{2+}$ concentrations in cultivated land showed declining trends, but with varying rates (Table 4). Exchangeable $\mathrm{Ca}^{2+}$ showed the highest decline, followed by exchangeable $\mathrm{Mg}^{2+}$ and CEC (Table 4).

\subsection{Relationships between selected soil properties}

SOM, TN, CEC, exchangeable $\mathrm{Ca}^{2+}$ and $\mathrm{Mg}^{2+}$, and $\mathrm{pH}$ are positively and significantly $(P<0.05$; Table 4$)$ associated with each soil property except with available $\mathrm{P}$, silt, and clay. In contrast, clay fraction is negatively and significantly $(P<0.05)$ associated with organic matter $(\mathrm{OM})$, total N, CEC, exchangeable $\mathrm{Ca}^{2+}, \mathrm{pH}$, and silt. SOM is significantly and strongly associated with $\mathrm{pH}$. This finding was in agreement with other studies carried out in different parts of the country (e.g., Amare et al., 2013; Asmamaw and Mohammed, 2013; Lelisa et al., 2010). Thus, the conversion of forestland into cultivated lands likely leads to the degradation of SOM. Since SOM is the major influence for $\mathrm{N}$ in the soil, soil-available $\mathrm{P}$, and CEC, it provides micronutrients through an effective soil food web. However, SOM in the soils of cultivated land can be increased through compost, cover crops, manures, minimum tillage, and crop rotation (Mikha et al., 2015; Martins et al., 2009). These can improve the concentration of physical, chemical, and biological soil parameters in the cultivated land.

There is no significant correlation between available $\mathrm{P}$ and any of the other chemical properties, most probably due to the generally low availability of potassium and the limited range of $\mathrm{pH}$ in the soil sampled. This finding does not agree with the fact that phosphorus availability is related to soil $\mathrm{pH}$. CEC is significantly and strongly associated with exchange- 
able $\mathrm{Ca}^{2+}, \mathrm{pH}$, and clay; exchangeable $\mathrm{Ca}^{2+}$ is significantly and strongly associated with $\mathrm{pH}$ and clay. This shows the ability of CEC to retain cations and the dependency of CEC upon the $\mathrm{pH}$ of the soil, soil nutrient retention capacity, and the capacity to protect groundwater from cation contamination. Exchangeable $\mathrm{Mg}^{2+}$ is significantly and strongly associated with $\mathrm{pH}$. On the other hand, clay is negatively correlated with all soil properties. The correlation was strong and statistically significant except for exchangeable $\mathrm{Mg}^{2+}$ and AP. Thus, clay in the soil has a negative influence on most soil properties. This suggests that both chemical and physical properties of soils are regulated by the clay properties of soil. Fantaw and Abdu (2011) and Lelissa et al. (2010) observed similar relationships.

\section{Conclusions}

The purpose of our study was to explore the effects of land use changes on the dynamics of soil properties and their implications for land degradation. The results indicate that cultivated land has the lowest organic matter, total nitrogen, cation exchange capacity, $\mathrm{pH}$, and exchangeable $\mathrm{Ca}^{2+}$ and $\mathrm{Mg}^{2+}$ contents compared to forestland and grazing land. Soil organic matter is lowest, and it is caused by land use changes, cropping pattern and frequency, the removal of crop residues, and faster decomposition and oxidation processes as well as soil erosion on cultivated lands. The losses of these essential elements may contribute to increasing degradation prevalence on cultivated land. Land degradation, in turn, impairs the capacity of land to contribute to food security. So as to increase soil organic matter and consequently enhance the concentration of other nutrients in the soil of cultivated land, we suggest an integrated implementation of land management through compost, cover crops, manures, minimum tillage, and crop rotation. Soils in the cultivated land are more acidic $(\mathrm{pH}<5.5)$ than those of the forestland and grazing lands. This may lead to aluminum and manganese toxicity, microbial conversion of $\mathrm{NH}_{4}^{+}$to nitrate will be slow, and crops with the ability to take up nitrate $\left(\mathrm{NO}_{3}^{-}\right)$will be negatively affected. Thus, we suggest the liming of cultivated land so as to increase soil $\mathrm{pH}$, supply essential plant nutrients $\left(\mathrm{Ca}^{2+}\right.$ and $\mathrm{Mg}^{2+}$ ), make other essential nutrients more available, and prevent $\mathrm{Mn}$ and $\mathrm{Al}^{-3}$ from being toxic to crop growth.

Acknowledgements. The authors wish to thank the farmers of the study area, who allowed the collection of extensive data from their farms. We are also grateful to the National Soil Laboratory Centre of the Ministry of Agriculture (MoA), Addis Ababa, Ethiopia.

Edited by: A. Cerdà

\section{References}

Abegaz, A., Winowiecki, A. A., Vågen, T.-G., Langan, S., and Smith, J. U.: Spatial and temporal dynamics of soil organic carbon in landscapes of the upper Blue Nile Basin of the Ethiopian Highlands, Agr. Ecosyst. Environ., 218, 190-208, 2016.

Amare, T., Terefe, A., Silasie, Y. G., Yitaferu, B., Wolfgramm, B., and Hurni, H.: Soil properties and crop yield along the terraces and toposequence of Anjeni watershed, central highlands of Ethiopia, J. Agric. Sci., 5, 134-144, 2013.

Angassa, A.: Effects of grazing intensity and bush encroachment on herbaceous species and rangeland condition in Southern Ethiopia, Land Degrad. Dev., 25, 438-451, 2014.

Asmamaw, L. and Mohammed, A.: Effects of slope gradient and changes in land use/cover on selected soil physic-biochemical properties of the Gerado catchment, Northeastern Ethiopia, Int. J. Environ. Stud., 70, 111-125, 2013.

Assefa, A. and van Keulen, H.: Modeling soil nutrient dynamics under alternative farm management practices in the Northern Highlands of Ethiopia, Soil Till. Res., 103, 203-215, 2009.

Barua, S. K. and Haque, S. M. S.: Soil characteristics and carbon sequestration potentials of vegetation in degraded hills of Chittagong, Bangladesh, Land Degrad. Dev., 24, 63-71, 2013.

Berendse, F., van Ruijven, J., Jongejans, E., and Keesstra, S. D.: Loss of plant species diversity reduces soil erosion resistance of embankments that are crucial for the safety of human societies in low-lying areas, Ecosystems, 18, 881-888, 2015.

Bewket, W. and Teferi, E.: Assessment of soil erosion hazard and prioritization for treatment at the watershed level: case study in the Chemoga watershed, Blue Nile basin, Ethiopia, Land Degrad. Dev., 20, 609-622, 2009.

Biro, K., Pradhan, B., Muchroithner, M., and Makeschin, F.: Land use/land cover change analysis and its impact on soil properties in the northern part of Gadarif region, Sudan, Land Degrad. Dev., 24, 90-102, 2013.

Bizoza, A. R.: Three-stage analysis of the adoption of soil and water conservation in the highlands of Rwanda, Land Degrad. Dev., 25 , 360-372, 2014.

Black, C. A., Evans, D. D., White, J. L., Newsmonger, L. E., and Clarkem, F. E.: Methods of Soil Analysis. Part 2: Wisconsin, American Society of Agronomy Inc., New York, 1965.

Cerdà, A.: The influence of aspect and vegetation on seasonal changes in erosion under rainfall simulation on a clay soil in Spain, Can. J. Soil Sci., 78, 321-330, 1998.

CSA: The 2007 Population and Housing Census of Ethiopia, Statistical Summary Report at National Level, Central Statistical Agency, Addis Ababa, Ethiopia, 2008.

De Mûelenaere, S., Frankl, A., Haile, M., Poesen, J., Deckers, J., Munro, N., Veraverbeke, S., and Nyssen, J.: Historical landscape photographs for calibration of Landsat Land use/cover in the Northern Ethiopian highlands, Land Degrad. Dev., 25, 319-335, 2014.

EMA - Ethiopian Metrological Agency: Data obtained and processed through personal communication, Addis Ababa, January 2013.

Emiru, N. and Gebrekidan, H.: Effect of land use changes and soil depth on soil organic matter, total nitrogen and available phosphorus contents of soils in Senbat watershed, western Ethiopia, J. Agric. Biol. Sci., 8, 206-212, 2013. 
Ermias, A., Shimelis, H., Laing, M., and Fentahun, M.: Aluminum tolerance in cereals: A potential component of integrated acid soils management in Ethiopia, Ethiop. J. Nat. Resour., 13, 4366, 2013.

Eyayu, M., Heluf, G. K., Tekalign, M., and Mohammed, A.: Effects of land use change on selected soil properties in the Tara Gedam catchment and adjacent agro-ecosystem, Northwest Ethiopia, Ethiop. J. Nat. Resour., 11, 35-65, 2009.

Fantaw, Y. and Abdu, A.: Soil property changes following conversion of acacia woodland into grazing and farmlands in the rift valley area of Ethiopia, Land Degrad. Dev., 22, 425-431, 2011.

Fantaw, Y., Ledin, S., and Abdu, A.: Changes in soil organic carbon and total nitrogen contents in three adjacent land use types in the Bale Mountains, south-eastern highlands of Ethiopia, Forest Ecol. Manage., 242, 337-342, 2007.

Karltun, E., Lemenih, M., and Tolera, M.: Comparing farmers' perception of soil fertility change with soil properties and crop performance in Beseku, Ethiopia, Land Degrad. Dev., 24, 228-235, 2013.

Keesstra, S. D., Bruijnzeel, L. A., and van Huissteden, J.: Mesoscale catchment sediment budgets: combining field surveys and modeling in the Dragonja catchment, southwest Slovenia, Earth Surf. Proc. Land., 34, 1547-1561, 2009.

Keesstra, S. D., Geissen, V., van Schaik, L., Mosse, K., and Piiranen, S.: Soil as a filter for groundwater quality, Curr. Opin. Environ. Sustain., 4, 507-516, 2012.

Kröpfl, A. I., Cecchi, G. A., Villasuso, N. M., and Distel, R. A.: Degradation and recovery processes in Semi-Arid patchy rangelands of northern Patagonia, Argentina, Land Degrad. Dev., 24, 393-399, 2013.

Lelissa, A., Hager, H., and Sieghardt, M.: Effects of land use types on soil chemical properties in smallholder farmers of central highland Ethiopia, Ekologia (Bratislava), 29, 1-14, 2010.

Martins, M., Cora, J., Jorge, R. F., and Marcelo, A. V.: Crop type influences soil aggregation and organic matter under no-tillage, Soil Till. Res., 104, 22-29, 2009.

Mekonnen, M., Keesstra, S. D., Stroosnijder, L., Baartman, J. E. M., and Maroulis, J.: Soil conservation through sediment trapping: A review, Land Degrad. Dev., 26, 544-556, 2015.

Mikha, M. M., Vigil, M. F., Liebig, M. A., Bowman, R. A., McConkey, B., Deibert, E. J., and Pikul, J. L.: Cropping system influences on soil chemical properties and soil quality in the Great Plains, Renew. Agricult. Food Syst., 21, 26-35, 2015.

Muñoz-Rojas, M., Jordán, A., Zavala, L. M., De La Rosa, D., AbdElmabod, S. K., and Anaya-Romero, M.: Impact of land use and land cover changes on organic carbon stocks in Mediterranean soils (1956-2007), Land Degrad. Dev., 26, 168-179, 2015.

Olsen, S. R., Cole, C. V., Watanabe, F. S., and Dean, L. A.: Estimation of available phosphorous in soils by Extraction with Sodium Bicarbonate, USDA, Department of Agriculture, Washington, D.C., 1954.
ORLEPB - Oromia Rural Land and Environmental Protection: Dhidhessa sub basin erosion hazard and land degradation Assessment, Vol. IV, Oromia Water Works Design and Super vision Enterprise (OWWDSE), Addis Ababa, Ethiopia, 2013.

Ouedraogo, E., Mando, A., and Stroosnijder, L.: Effects of tillage, organic resources and nitrogen fertilizer on soil carbon dynamics and crop nitrogen uptake in semi-arid West Africa, Soil Till. Res., 91, 57-67, 2006.

Parras-Alcántara, L., Martín-Carrillo, M., and Lozano-García, B.: Impacts of land use change in soil carbon and nitrogen in a Mediterranean agricultural area (Southern Spain), Solid Earth, 4, 167-177, doi:10.5194/se-4-167-2013, 2013.

Saha, D. and Kukal, Z. P.: Soil structural stability and water retention characteristics under different land uses of degraded 5 lower Himalayas of North-West India, Land Degrad. Dev., 26, 263271, 2015.

Tesfahunegn, G. B.: Soil quality indicators response to land use and soil management systems in Northern Ethiopia's catchment, Land Degrad. Dev., 27, 438-448, doi:10.1002/ldr.2245, 2016.

Tesfaye, A., Negatu, W., Brouwer, R., and Van Der Zaag, P.: Understanding soil conservation decision of farmers in the Gedeb Watershed, Ethiopia, Land Degrad. Dev., 25, 71-79, 2014.

Thompson, S. K.: Adaptive cluster sampling: Designs with primary and secondary units, Biometrics, 47, 1103-1115, 1991.

Vågen, T.-G. and Winowiecki, L. A.: Mapping of soil organic carbon stocks for spatially explicit assessments of climate change mitigation potential, Environ. Res. Lett., 8, 1-3, 2013.

Vågen, T.-G., Winowiecki, L. A., Abegaz, A., and Hadgu, K. M.: Landsat-based approaches for mapping of land degradation prevalence and soil functional properties in Ethiopia, Remote Sens. Environ., 134, 266-275, 2013.

Walkely, A. and Black, C. A.: An examination of the Degtjareff method for determining soil organic matter and a proposed modification of the chromic acid titration method, Soil Sci., 37, 2938, 1934.

Yao, M. K., Angui, P. K., Konaté, S., Tondoh, J. E., Tano, Y., Abbadie, L., and Benest, L.: Effects of land use types on soil organic carbon and nitrogen dynamics in mid-west Côte d'Ivoire, Eur. J. Sci. Res., 40, 211-222, 2010.

Yeshanew, A., Zech, W., and Guggenberger, G.: Transformation of a Podocarpusfalcatus dominated natural forest into a monoculture Eucalyptus globulus plantation at Munesa, Ethiopia: soil organic $\mathrm{C}, \mathrm{N}$ and $\mathrm{S}$ dynamics in primary particle and aggregate-size fractions, Agr. Ecosyst. Environ., 106, 89-98, 2005.

Zeng, D. H., Hu, Y. L., Chang, S. X., and Fan, Z. P.: Land cover change effects on soil chemical and biological properties after planting Mongolian pine in sandy lands in Keerqin, northeastern China, Plant Soil, 317, 121-133, 2009.

Zhang, T., Wang, Y., Wang, X., Wang, Q., and Han, J.: Organic carbon and nitrogen stocks in reed meadow soils converted to alfalfa fields, Soil Till. Res., 105, 143-148, 2009. 